Universität Konstanz, Fakultät für Biologie, Lebrstubl für Phytopathologie, D-7750 Konstanz

\title{
The Differentiation of Infection Structures as a Result of Recognition Events between some Biotrophic Parasites and their Hosts
}

\author{
K. Mendgen, A. Schneider, M. Sterk and W. Fink \\ Authors' address: K. MENDGEN, A. SCHNEIDER, M. STERK, and W. Fink, Universität Konstanz, \\ Fakultät für Biologie, Lehrstuhl für Phytopathologie, D-7750 Konstanz (F.R.G.).
}

With 7 figures

Received March 24, 1988; accepted May 10, 1988

\begin{abstract}
Most uredospores of rust fungi develop infection structures in a typical pattern so that they can infect the host plant. The function of these infection structures is divided into the following three phases:

1. In the recognition phase, the germ tube recognizes the cuticle and the stoma. This process may occur independently from the host plant since copies of the cuticle induce similar reactions of the fungus. During fungal growth on the epidermis, unspecific stress responses of the plant are triggered.

2. In the signal phase, the fungal substomatal vesicle and infection hypha(e) contact the host cells within the leaf parenchyma. A signal from the host induces further development of the fungus. Haustorium mother cell differentiation is effected and haustorium formation is initiated. At the same time, the fungus suppresses the synthesis of stress metabolites by the plant.

3. In the parasitic phase, the fungus penetrates the host cell and complex interactions between host and parasite begin. A highly specialized interface around the haustorium develops presumably in order to allow a more efficient nutrient transfer from host to parasite. Eventual defence reactions of the plant, generally on the race-cultivar level, fail to be evoked or are suppressed in compatible combinations.
\end{abstract}

\section{Zusammenfassung}

Die Ausbildung von Infektionsstrukturen als Folge von Erkennungsreaktionen zwischen einigen biotrophen Parasiten und ihren Wirtspflanzen

Der Infektionsverlauf der dikaryotischen Uredospore der Rostpilze wird in die folgenden drei Phasen unterteilt:

1. In der Erkennungsphase erkennt der Keimschlauch die Kutikula und die Spaltöffnung. Dieser Vorgang kann auch unabhängig von der Wirtspflanze ablaufen, da ein Abdruck der Pflanzen-

Presented on the occasion of the 60th birthday of Prof. Dr. R. Herrefuss in Göttingen. 
oberfläche ähnliche Reize für den Pilz abgibt. Während des Wachstums des Pilzes auf der Epidermis wird bei der Wirtspflanze die Synthese von Streßmetaboliten ausgelöst.

2. In der Signalphase nehmen das substomatäre Vesikel und die Infektionshyphe des Pilzes Kontakt mit den Parenchymzellen im Blatt auf. Ein Signal der Wirtszellen induziert die weitere Entwicklung des Pilzes. Gleichzeitig unterdrückt der Pilz die weitere Synthese von allgemeinen Streßmetaboliten der Wirtspflanze.

3. In der parasitischen Phase dringt der Pilz in die Wirtszelle ein und komplizierte Wechselwirkungen zwischen Wirt und Parasit beginnen. Eine hochspezialisierte Interaktionszone in der Umgebung des Haustoriums entwickelt sich, wahrscheinlich um einen möglichst effektiven Transport von Metaboliten aus der Wirtszelle in das Pilzhaustorium zu ermöglichen. Weitere Abwehrreaktionen der Wirtszelle, hervorgerufen durch mehr oder weniger virulente Pilzrassen, werden vermieden oder unterdrückt.

Many plant pathogenic fungi differentiate specialized infection structures in order to penetrate into their host. In the monokaryotic phase, the basidiospore of the rust fungus Uromyces appendiculatus forms only a short germ tube before it differentiates an appressorium on the epidermis and perforates the cuticle. Within the epidermal cell, an intraepidermal vesicle develops from which hyphae start to colonize the host leaf (GOLD and MendGen 1984). The induction of these infection structures is nonspecific. The isolated cuticle of the host plant or even $5 \%$ agar induce the formation of the intraepidermal vesicle (FREYTAG et al. 1988).

In the dikaryotic phase, most rust fungi develop more complex infection structures (Fig. 1 a): The germ tube crosses the array of wax crystals on the cuticle (JOHNSON 1934) and grows towards a stoma. When the tip of the germ tube contacts the stomatal opening, appressorium formation begins. From the lower surface of the appressorium, an infection peg develops and penetrates into the substomatal cavity of the leaf where the substomatal vesicle with the infection hypha is formed. After close contact with the parenchymatous host cells, a haustorial mother cell develops which, in turn, differentiates a haustorium in the host cell. This sequence of specific infection structures seems to be the product of specific interactions between the host and the parasite. In this paper, three main phases, during which responses are triggered either by host and/or parasite, are discussed. These are the recognition, signal and parasitic phases (Fig. 1 b).

\section{The recognition phase}

After dissemination, the germination inhibitor in the rust uredospores diffuses away if there is sufficient moisture and the spore begins to germinate if light, temperature and water quality parameters allow this (see STAPLES and MACKO 1984). The germ tube grows in close contact with the cuticle. In wheat, the wax crystal array of the host cuticle (LEwIS and DAY 1972), and the surface depressions located at anticlinal walls of epidermal cells, induce directed growth that increases the probability of the germ tube meeting a stoma. Gradients in $\mathrm{pH}$ at the leaf surface also influence the direction of germ tube growth of Uromyces viciae fabae (EDWARDS and BOWLING 1986). The tuning of germ tube tropism is very well adapted to the host plant surface since the different rust fungi find the 
Fig. 1. Infection structures of the dikaryotic uredospore of most rust fungi

a) morphological characterization

b) functional characterization
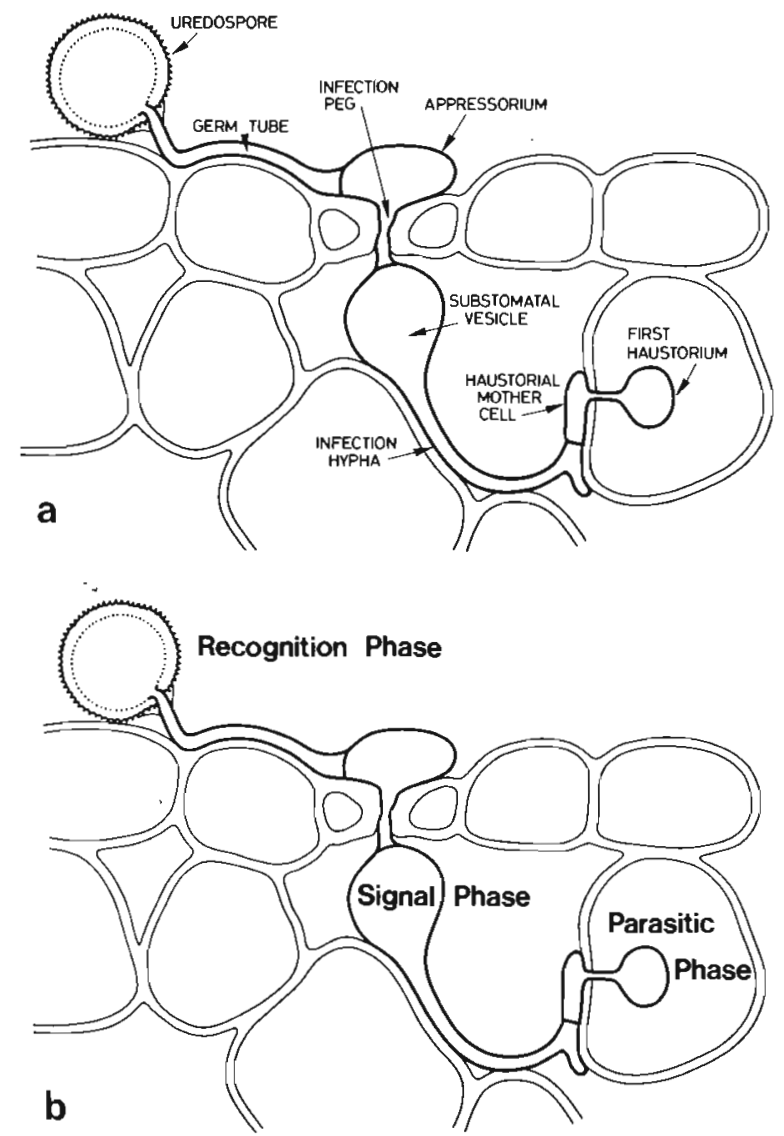

stomata of their respective hosts with great accuracy (HEATH 1974). As soon as the fungus reaches the outer stomatal lip, appressorium formation is initiated. As a result genes are expressed to initiate mitosis and formation of new wall layers (see Hoch and STAPLES 1987).

The mechanism(s) by which stomata signal appressorium differentiation is not yet clearly understood. HocH et al. (1987) have shown for the bean rust fungus that a single $0.5 \mu \mathrm{m}$ deep scratch on a hard surface can replace this signal and that the depth of the scratch corresponds to the height of the stomatal lip. It is completely independent of the host plant. The signal can also be mimicked by treating the germ tube with heat $\left(1 \mathrm{~h}\right.$ at $30^{\circ} \mathrm{C}$ ) (MaHEswari and HildebrandT 1967), acrolein (MACKO et al. 1978), substances from the leaf cuticle (GRAMBOW and Reisener 1976), ions and nucleotides (Staples et al. 1983) or light (PAvgi and Dickson 1961). The sensitivity of the different rusts to such treatments varies considerably. Collodion-oil membranes are inductive for most rust fungi, but not for Puccinia recondita (FREYTAG, Konstanz, unpublished). The soybean rust fungus (Phakopsora pachyrbizi) will form appressoria on glass slides and on $5 \%$ water agar (KiTANi and INOUE 1961, KocH 1984). 
STAPLES and HocH (1982) first suggested that the sensing mechanism involves elements of the cytoskeleton of the hypha since as soon as appressorium formation is initiated, the microtubules and the F-actin cytoskeleton at the tip of the hypha are oriented parallel to the stomatal lips and a message starts (BOURETT et al. 1987). If there is such a signal chain between the hyphal tip and the nucleus to induce mitosis, the different modes of appressorium induction should either interfere with this signal chain or have the same effect on the hyphal tip. A second messenger system could be involved in this signal chain (STAPLES and HOCH 1987). We only know that the receptor at the hyphal tip is extremely sensitive, that the signal can be independent of the host (WYNN 1976), and is mediated by proteinase sensitive structures of the extracellular matrix of the germ tube (EPSTEIN et al. 1985).

During the germ tube growth on the leaf, the rust fungus elicits general defence reactions of the plant, such as the production of stress metabolites (YAMAMOTO et al. 1977) or the synthesis of ethylene (see PARADIES and ELSTNER 1980). Similarly, constituents of the germ tubes of rust fungi may induce the synthesis of phytoalexins in bean (Phaseolus vulgaris) leaves (HOPPE et al. 1980) or trigger the synthesis of lignin in wheat (Triticum aestivum) (MOERSCHBACHER et al. 1986). Chitin or chitosan also may elicit such defence reactions (Young et al. 1982, Darvill and Albersheim 1984). As with most other carbohydrate elicitors, the chitin detectable on the surface of the germ tubes of $U$. appendiculatus and $U$. vignae does not show race specific differences in its affinity to wheat germ agglutinin (Fig. 2). Also, the proteins with carbohydrate moieties in the germ tubes of $P$. graminis exhibit no race specificity (KIM and Howes 1987) after two-dimensional gel electrophoresis.

\section{The signal phase}

After the differentiation of the appressorium, a penetration peg develops from this appressorium, grows into the substomatal cavity of the leaf and further differentiates a substomatal vesicle. The cytoplasm accumulates in this vesicle which then elongates to form the infection hypha. A second round of nuclear division occurs. The fungus is in very close contact with the host parenchymatous cells and there seems to be an exchange of specific signals between host and parasite. Many arguments favor this assumption:

$6-14 \mathrm{~h}$ after inoculation, when the rust fungus has differentiated the appressorium and proliferates in the substomatal chamber, the ethylene production induced by bean rust ( $U$. appendiculatus) germ tubes is reduced (PARADIES et al. 1979, Paradies and Elstner 1980). During the same period, in crown rust (Puccinia coronata) inoculated Avena leaves, the activity of phenylalanine ammonia-lyase (YAMAMOTO et al. 1977) and lipoxygenase (YAMAMOTO and TANI 1986) decrease during development of the infection hypha. Wall deposits (ONOE et al. 1987) can be observed on those cells that surround the stomata (subsidiary cells). All these unspecific reactions of the host cells are suppressed during subsequent growth of the infection hypha and secondary hyphae in the leaves. At the same time that the non-specific host responses begin to be suppressed, the rust 


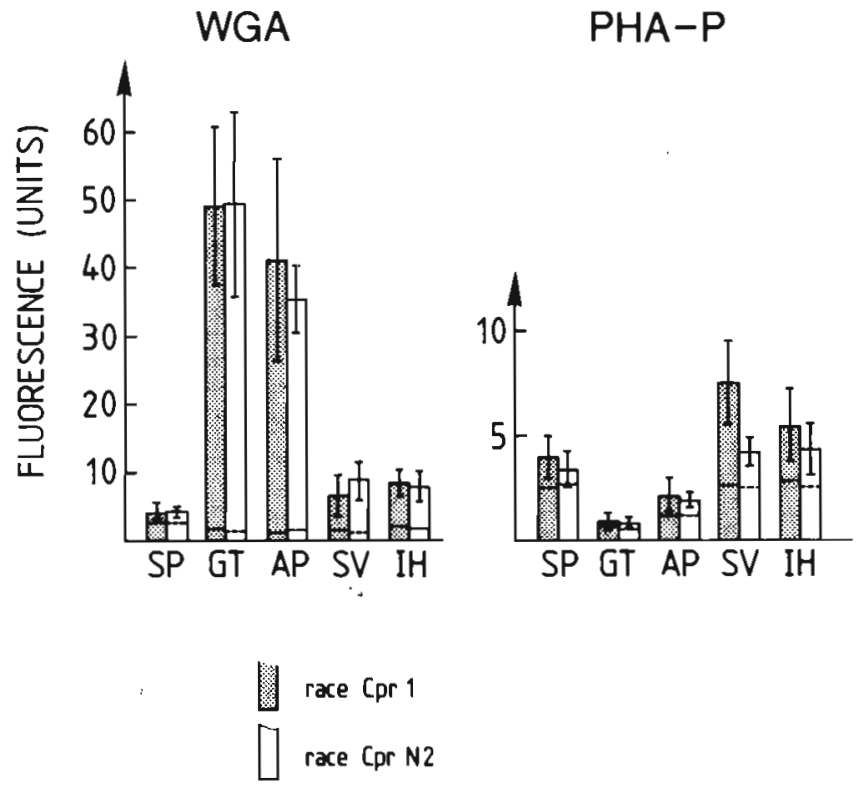

Fig. 2. Adhesion of the FITC labelled lectin of Triticum vulgaris (WGA) and the lectin of Phaseolus vulgaris (PHA-P) to the infection structures of the Uromyces vignae races $\mathrm{C}_{\mathrm{pr}} 1$ and $\mathrm{Cpr} \mathrm{N} 2$. The affinity of the lectin to the infection structures was estimated by measuring the fluorescence with a microscope photometer (MENDGEN et al. 1985). The specificity of the binding was characterized by preincubation with the following inhibiting sugars: hydrolysate of chitin for WGA and N-acetyl-Dgalactosamine for PHA-P. The fluorescence of the controls is indicated by a dotted line $\left(\Gamma^{-} 1\right)$. $\mathrm{SP}=$ spore $; \mathrm{GT}=$ germ tube $; \mathrm{AP}=$ appressorium $; \mathrm{SV}=$ substomatal vesicle $; \mathrm{IH}=$ infection hypha

fungus changes drastically its surface characteristics. The walls of all infection structures of Phacopsora pachyrhizi and P. graminis contain chitin (EBRAHIMNesbat et al. 1985, Harder et al. 1986). The chitin extends to the outer surface of the germ tube matrix in all rust fungi tested (Kapooria and Mendgen 1985). During appressorium formation, the fungus starts to cover the chitin with $\beta-1-3$ and $\beta-1-6$ glucans. Virtually no chitin can be detected on the surface of the infection hypha (MENDGEN et al. 1985). From this outer layer with the glucans project some few carbohydrates that differ in the rust races tested. Two races of Uromyces vignae, Cpr 1 and Cpr N 2 show different affinities to the Phaseoluslectin (PHA-P). This indicates that race specific molecules on the infection hyphae differ in their composition of $\mathrm{N}$-acetyl-D-galactosamine or a similar sugar (Fig. 2). Also, two races of Uromyces appendiculatus (GBR und RBR 1) differ in their binding to the Lens culinaris lectin and the Bandeira simplicifolia lectin. Obviously, race specific molecules on the substomatal vesicle and the infection hyphae differ in their mannose and terminal $\mathrm{N}$-acetylglucosamine residues (Fig. 3) or similar molecules.

We suggest, that the surface carbohydrates of the infection hypha, which are species-specific, but also have some race-specific components, may be involved in 


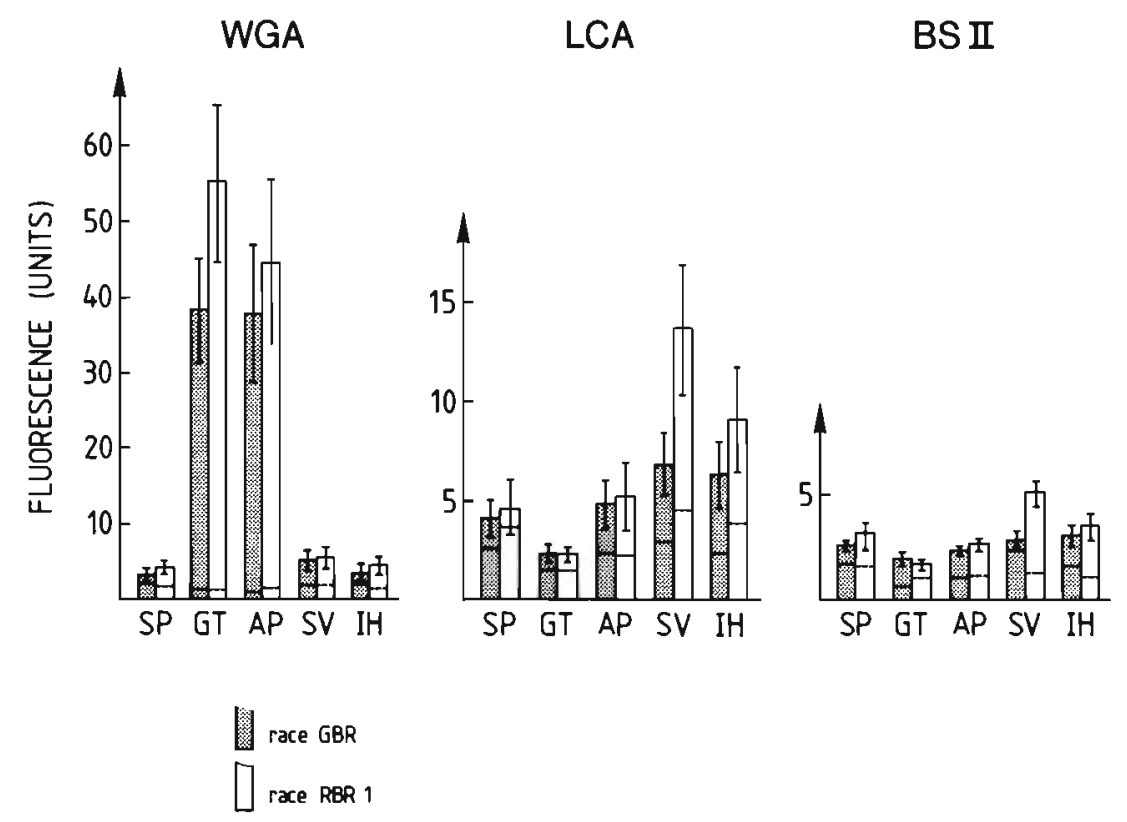

Fig. 3. Adhesion of FITC labelled lectin of Triticum vulgaris (WGA), inhibitor: hydrolysate of chitin, the lectin of Lens culinaris (LCA), inhibitor: $\alpha$-methyl-D-mannopyranoside, and the lectin of Bandeira simplicifolia (BS-II), inhibitor: $\mathrm{N}$-acetyl-D-glucosamine, to the infection structures of Uromyces appendiculatus. The races were isolated in Göttingen (GBR) and in Konstanz (RBR 1). See

Fig. 2 for measurement of binding

the suppression of defence reactions of the plant. Such defence reactions include the synthesis of stress compounds mentioned above. Similar suppression can be obtained by treatment of leaf rust $(P$. hordei) infected barley with actinomycin, an inhibitor of RNA synthesis (RWENDEIRE $e$ t al. 1988). A suppression of host plant stress reactions during fungal invasion was found also in other host-parasite systems: A transient induction of ammonia-lyase and of 4-coumarate : CoA ligase mRNAs occurs after infection with Pbytophthora infestans (FrITZEMEIER et al. 1987). In the latter host-parasite system, suppressors of hypersensitive cell death have been detected (DOKE et al. 1979), and in a similar system, P. megasperma on soybeans, suppressors of phytoalexin synthesis were found (ZIEGLER and PONTZEN 1982). Although each host-parasite system is unique, and although correlative studies of physiological and morphological events during the early stages of infection are often missing, it is obvious that during each step of infection, the subsequent progress of infection is determined (HEATH 1974).

In the rust system, the interactions between the two partners may in part be mediated by a fibrillar layer on the intercellular hyphae. The layer becomes visible after high-pressure freezing and freeze substitution with $4 \%$ osmic acid in acetone (Fig. 4). These fibrils are in close contact with the host wall and may even project into the host walls. They are barely visible after conventional preparation for electron microscopy (MENDGEN 1973) because they are probably washed away during processing. This material may be part of the so-called intercellular washing 
Fig. 4. Electronmicrograph of an intercellular hypha of Puccinia coronata after high pressure freezing (see MULLER and MOOR 1984) and freeze substitution in acetone for $24 \mathrm{~h}$ at $-90^{\circ} \mathrm{C}$, followed by a treatment with $4 \% \mathrm{OsO}_{4}$ in acetone at $-90^{\circ} \mathrm{C},-60^{\circ} \mathrm{C},-30^{\circ} \mathrm{C}$ and $0{ }^{\circ} \mathrm{C}$ during $24 \mathrm{~h}$ for each step. The wall of the fungus $(w)$ is covered with a layer of fibrillar structures $(\times 28,000)$

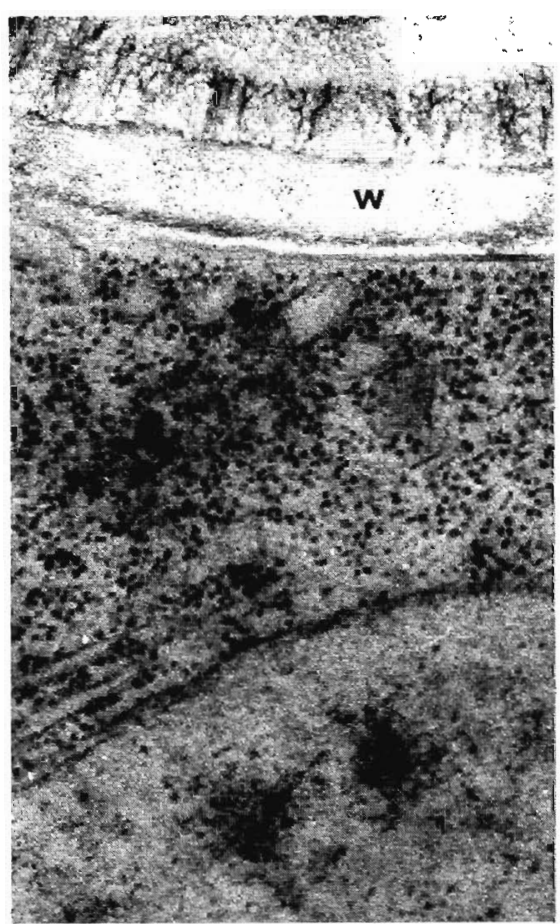

fluid (IWF) which is obtained after infiltration of rust-infected wheat leaves with buffer and subsequent gentle centrifugation. ROHRINGER and MARTENS (1987) detected race specific proteins in this IWF. Some molecules bind to concavalin A which indicates that they also contain $\alpha$-linked glucose or mannose and appear to originate from the fungus (HOLDEN and ROHRINGER 1985). Unfortunately, we have no proof that these differences are responsible for pathogenicity of the two races or whether they are part of gene specific interactions.

It is obvious from these studies that the contact of the rust hyphae with the host parenchymatous wall plays an important role in regulating the interaction between both partners. The molecules responsible for the interaction may be secreted by a special secretory system detected in infection hyphae and in all subsequent stages of the fungus (KNAuF and MENDGEN 1988, Welter et al. 1988). Since we have a species specific monoclonal antibody (Fig. 5) that recognizes molecules of only the substomatal vesicle and the infection hyphae, it seems possible to isolate and follow the synthesis and secretion of species-specific molecules. It is conceivable, that the species-specific molecules secreted at this stage of development suppress or elicit in the non-host plant the host defences. Such molecules may play a role in establishment of basic compatibility or elicitation of non-host resistance mechanisms (see HEATH 1987).

The plant also influences the development of the infection hypha. After the induction of the appressorium in vitro, some rust fungi (e.g. the soybean rust (Ph. pachyrhizi) and the coffee rust (Hemileia vastatrix) (S. FREYTAG, Konstanz, 

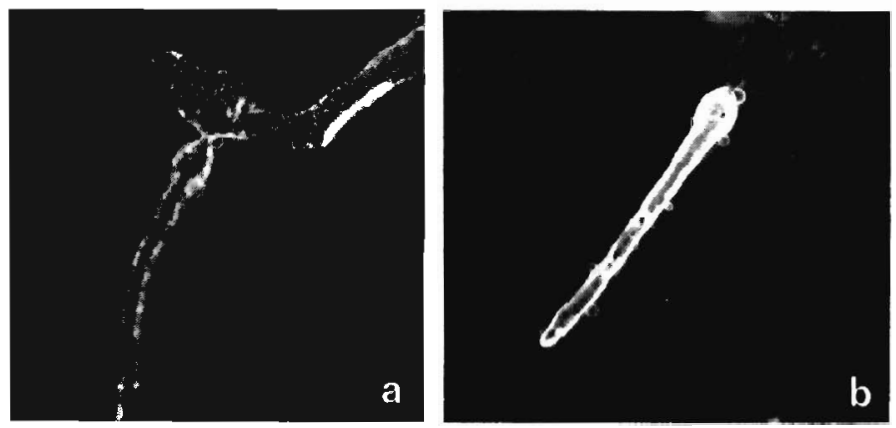

Fig. 5. Polyclonal serum recognizing the infection structures of Uromyces vignae (a). Monoclonal, species specific and differentiation specific antibody (b) that recognizes only the substomatal vesicle and the infection hypha of $U$. vignae. The antibodies were labelled with FITC-conjugated goatantimouse $\operatorname{IgG}+\operatorname{IgM}$

unpublished) stop further differentiation whereas others proceed to develop the substomatal vesicle and the infection hyphae. Other rusts like the broad bean rust (U. viciae fabae) (FREYTAG, Konstanz, unpublished result) and the cowpea rust (Heath and Heath 1978) even differentiate haustorial mother cells. But no typical haustorium has been observed in vitro up to now. Obviously, the fungus needs to contact the wall of a living host parenchyma cell (MENDGEN 1982). Also, since fungal growth frequently stops after formation of the haustorial mother cell in non-host plants (Elmhirst and HeAth 1987, Niks 1983, Luke et al. 1987), the host plant seems to "encourage" penetration and differentiation of the haustorium (Stumpf and Heath 1985, Heath and StumpF 1986). This could be mediated by molecules from the host protoplast and/or from the outside of the wall. In order to isolate and study such molecules, the influence of the intercellular washing fluid on infection structures grown in vitro was studied. This IWF contains, depending on the resolution of the separation technique, four to six $\beta-1-3$ glucanases (Fig. 6) and four chitinases which may attack the fungal wall and

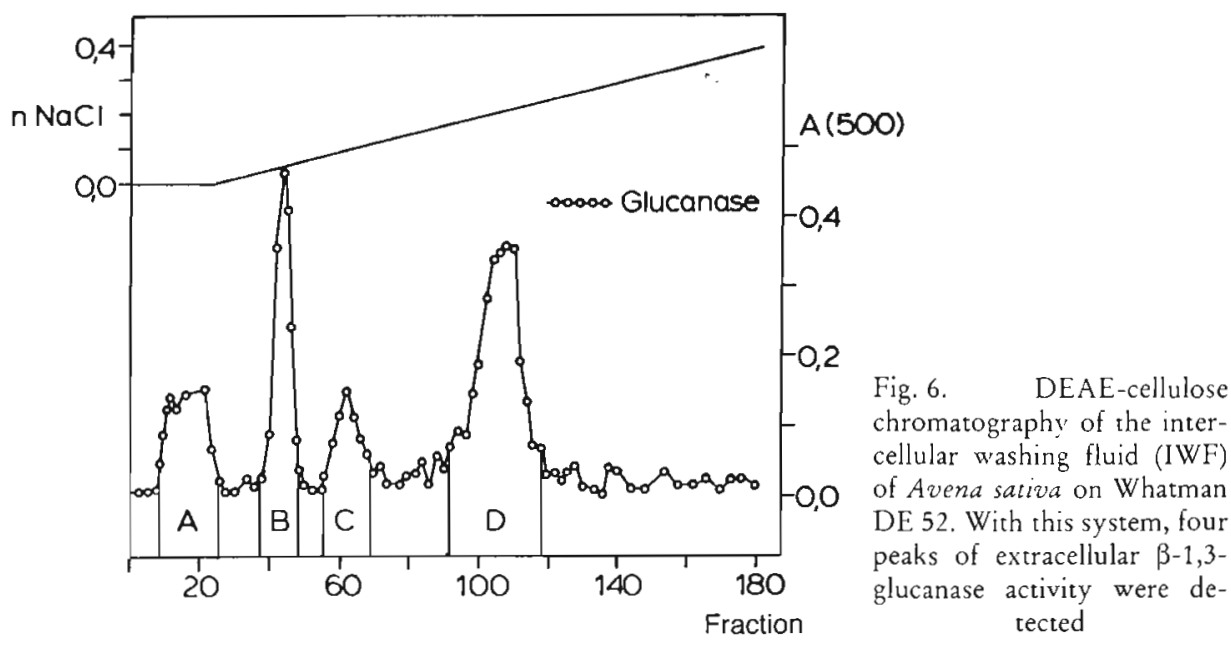


liberate "messenger" molecules (FINK et al. 1988). However, neither a deleterious effect on the infection hyphae nor the induction of haustoria has been observed (MENDGEN, unpublished result).

\section{The parasitic phase}

The parasitic phase of the dikaryotic rust mycelium starts either with haustorial mother cell differentiation or with the penetration of the host cell wall. First, a haustorial neck with its neck ring forms within the host cell. This neck distally enlarges and the haustorial body differentiates (HARDER and CHONG 1984, Heath and Heath 1975, Littlefield and Heath 1978). The host plant may accumulate very specific membrane structures around the haustorium. Complexes induced by $P$. graminis in wheat or oats are the same, but those induced by $P$. coronata in oats are very different. This means that fungus species-specific changes are induced in the host protoplast (CHONG and Harder 1982, Harder et al. 1978). In all rust fungi studied up to now, the haustorium itself is surrounded by the extrahaustorial membrane. Although this membrane is continuous with the host plasmalemma, it differs considerably from the normal plasmalemma. It has different affinities to some stains (see LitTlefield and HeatH 1979, Harder and CHONG 1984), a much lower sterol content (HARDER and MENDGEN 1982) and lacks intra membrane particles and AT'Pase activity (LitTLEFIELD and BraCKER 1972, Spencer-Philips and Gay 1981). The meaning of these qualities is not understood yet. Perhaps, the fungus induces a modification of the plasmalemma

Fig. 7. Mitochondria in the haustoria of Erysipbe graminis f. sp. bordei were stained with the potentiometric cyanine dye, $\mathrm{DiOC}_{4}(3)$ and the fluorescence of these mitochondria was measured. The arrow indicates the stage at which the host cells were floated on a solution with $50 \mathrm{mM} \mathrm{D-glu-}$ cose (O) or $25 \mathrm{mM}$ sucrose

(a). Buffer control:

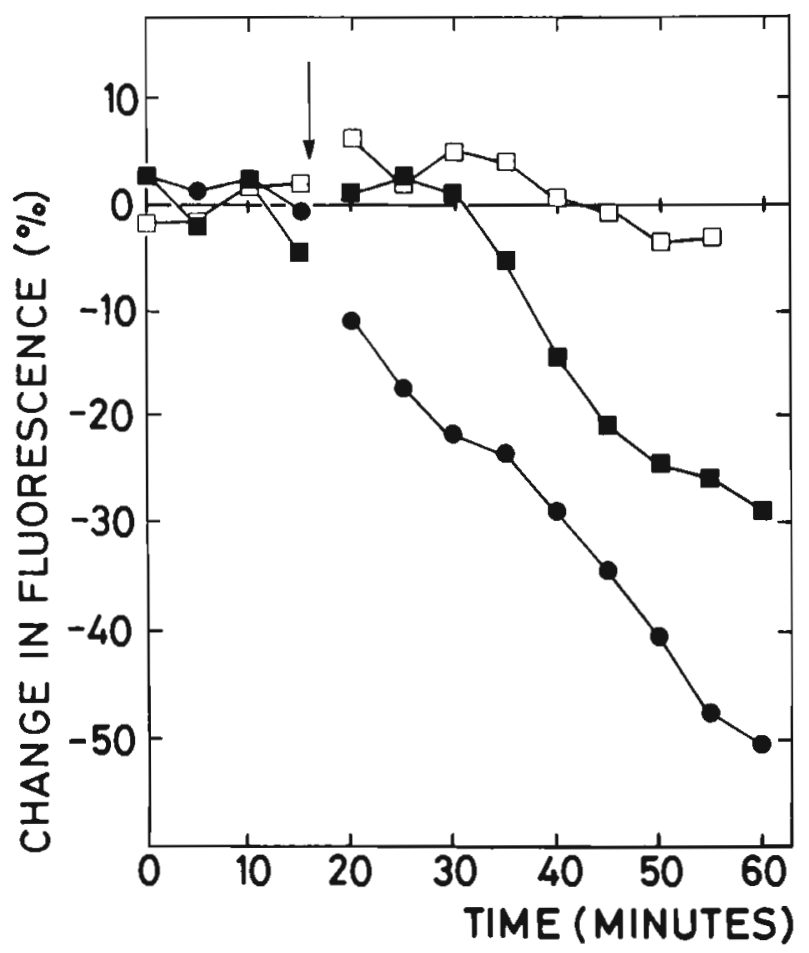


around the haustorium that facilitates the flow of nutrients. In the rusts, we have no idea yet what nutrients are transferred from host to parasite (MENDGEN 1981).

In the case of the barley powdery mildew haustorium (Erysiphe graminis $\mathrm{f}$. sp. hordei), we have evidence now that glucose is the sugar preferably transported from host to parasite. To show this, the membrane potential of haustorial mitochondria was studied with a potentiometric cyanine dye (BusHNell et al. 1987) which exhibits fluorescence in a polarized membrane. We assumed that the sugar which reaches the haustorium would first increase respiration there. As a consequence, the membrane potential of mitochondria increases. This increase of membrane potential was detected by measuring the quenching of fluorescence in mitochondria. An immediate effect was detected after feeding with glucose. The response was proportional to the glucose concentration added. Sucrose induced a reaction about 15-20 minutes later (Fig. 7). Galactose and L-glucose had no effect (MENDGEN and Nass 1988).

The events that induce this highly specialized interface between both partners and keep it in a balanced state, i.e. suppress host defence reactions and induce the flow of nutrients towards the parasite are completely unknown. In incompatible combinations, host defences generally begin at this stage of development. Protein synthesis again starts during differentiation of the rust haustorium and phenylalanine ammonia lyase, lipoxygenase and other enzyme activities increase (Yamamoto et al. 1977, Yамамото and TANi 1986). Also, phytoalexins are synthesized in oat tissue at this stage of the host-parasite interaction (MAYAMA 1982). Synthesis of phytoalexins, however, may not be correlated directly with resistance against bean rust infection (Hoppe et al. 1980). These reactions of the host seem to be regulated by the products of race specific genes (KEEN 1982). The effect can be abolished with antibiotics (TANI and YAMAmOTO 1978) and the plant becomes susceptible again. Similar events can be observed in barley powdery mildew (E.graminis f. sp. hordei) infected leaf tissue. Populations of mRNA increase during penetration of $E$. graminis and decrease after haustorium differentitation in a compatible combination (DAvidSON et al. 1988). At the same stage of haustorial development, defence reactions against nonhost haustoria may be suppressed during the following one or two days (KunOH 1987). The regulation of such processes is still unknown. Perhaps, the extrahaustorial matrix that separates host and parasite contains the molecules that trigger or switch off the host responses. Unfortunately, these walls are not accessible to chemical analysis. Therefore, more studies are needed to prove that, during haustorium formation (i.e. the parasitic phase), a new type of interaction between host and parasite begins and is responsible for the defence reactions of the plant at the level of race specificity.

\section{Conclusions}

It is obvious that there are more or less specific interactions between host and parasite during the different stages of infection. Changes in the surface structure of the cuticle may lead the fungus astray. During the initial contact in the substomatal cavity, signal molecules may stop or encourage the successful 
colonization of the host. Even more delicate interactions occur during the parasitic phase when most race-specific interactions leading to compatibility or incompatibility are expressed. However, we have as yet no sound explanation for species- or race specific interactions. Also, we have no evidence for factors which lead to "horizontal" or "vertical" interactions (VAnderplank 1984). Perhaps a precise knowledge of the early interactions will improve our understanding of host and parasite and will explain the differences between species- and race specificity.

We want to thank the following colleagues and students. Dr. M. HEATH, Toronto, supplied the races of the cowpea rust and Dr. M. MÜLLER, ETH Zürich, allowed us to use the high pressure freezing instrument. Mrs. U. SCHwanz produced the monoclonal antibodies and Drs. D. E. Harder, F. H. J. Rijkenberg, R. Rohringer and Mary Ann Stumpr helped with the manuscript. The Deutsche Forschungsgemeinschaft supported K. M. with grants.

\section{Literature}

Bourett, T., H. C. Hoch, and R. C. STAPles, 1987: Association of the microtubuli cytoskeleton with the thigmotropic signal for appressorium formation in Uromyces. Mycologia 79, $540-549$.

Bushnell, W. R., K. MendeEN, and Z. Liu, 1987: Accumulation of potentiometric and other dyes in haustoria of Erysiphe graminis in living host cells. Physiol. Mol. Plant Pathol. 31, 237-250.

Chong, J., and D. E. HaRder, 1982: Ultrastructure of haustorium development in Puccinia coronata avenae: Some host responses. Phytopathology 72, 1527-1533.

Darvill, A. G., and P. Albersheim, 1984: Phytoalexins and their elicitors - a defence against microbial infection in plants. Annu. Rev. Plant Physiology 35, 243-275.

Davidson, A. D., J. M. Manners, R. S. Simpson, and K. J. Scott, 1988: Altered host gene expression in near-isogenic barley conditioned by different genes for resistance during infection by Erysiphe graminis f. sp. bordei. Physiol. Mol. Plant Pathol. 32, 127-139.

DOKE, N., N. A. GARAS, and J. KUC, 1979: Partial characterization and aspects of the mode of action of a hypersensitivity-inhibiting factor (HIF) isolated from Phytophthora infestans. Physiol. Plant Parhol. 15, 127-140.

Ebrahim-Nesbat, F., H. H. Hoppe, and R. Rohringer, 1985: Lectin binding studies on the cell walls of soybean rust (Phakopsora pachyrhizi Syd). Phytopath. Z. 114, 97-107.

EDwARDs, M. C., and D. J. F. BowLING, 1986: The growth of rust germ tubes towards stomata in relation to $\mathrm{pH}$ gradients. Physiol. Mol. Plant Pathol. 29, 185-196.

Elmhirst, J. F., and M. C. HearH, 1987: Interactions of the bean rust and cowpea rust fungi with species of the Phaseolus-Vigna plant complex. I. Fungal growth and development. Can. J. Bot. 65, 1096-1107.

Epstein, L., L. Lacetti, R. C. Staples, H. C. Hoch, and W. A. Hoose, 1985: Extracellular proteins associated with induction of differentiation in bean rust uredospore germlings. Phytopathology 75, 1073-1076.

Fink, W., M. Lrefland, and K. MendGen, 1988: Chitinases and $\beta$-1,3-glucanases in the apoplastic compartment of oat leaves (Avena sativa L.). Plant Physiol. (in press).

Freytag, S., L. Bruscaglioni, R. E. Gold, and K. Mendgen, 1988: Basidiospores of rust fung: (Uromyces species) differentiate infection structures in vitro. Exp. Mycology (in press).

Fritzemeier, K. H., C. Cretin, E. Kombrink, F. Rohwer, J. Taylor, D. Scheel, and K. HAHLBROCK, 1987: Transient induction of phenylalanine ammonia-lyase and 4-coumarate: $\mathrm{CoA}$ ligase mRNAs in potato leaves infected with virulent or avirulent races of Phytophthora infestans. Plant Physiol. 85, 34-41.

GOLD, R. E., and K. MENDGEN, 1984: Cytology of basidiospore germination, penetration and early colonization of Phaseolus vulgaris by Uromyces appendiculatus var. appendiculatus. Can. J. Bot. 62, 1989-2002. 
Grambow, H. J., und H. J. ReISENer, 1976: Differenzierung und Wachstum von Puccinia graminis $\mathrm{f}$. sp. tritici in vitro. Ber. Dtsch. Bot. Ges. 89, 555-561.

Harder, D. E., R. Rohringer, D. J. SAmborski, W. K. Kim, and J. Chong, 1978: Electronmicroscopy of susceptible and resistant near isogenic $(\mathrm{sr} 6 / \mathrm{S} r 6)$ lines of wheat infected by Puccinia graminis tritici. I. The host-pathogen interface in the compatible (sr6/P6) interaction. Can. J. Bot. 56, 2955-2966.

- - , and K. MENDGEN, 1982: Filipin-sterol complexes in bean rust- and oat crown rust-fungal/plant interactions: Freeze-etch electron microscopy. Protoplasma 112, 46-54.

- - , and J. CHONG, 1984: Structure and physiology of haustoria. In: BusHNELL, W. R., and A. P. RoElfs (Eds), The Cereal Rusts, pp. 431—476. Academic Press, Orlando.

- - , - - R. ROHRINGer, and W. Kim, 1986: Structure and cytochemistry of the walls of urediospores, germ tubes, and appressoria of Puccinia graminis tritici. Can. J. Bot. 64, $476-485$.

HEATH, M. C., 1974: Light and electron microscope studies of the interactions of host and non-host plants with cowpea rust - Uromyces phaseolivar. vignae. Physiol. Plant Pathol. 4, 403-414.

- - , and I. B. HeatH, 1975: Ultrastructural changes associated with the haustorial mother cel] during haustorium formation in Uromyces phaseoli var. vignae. Protoplasma 84, 297-314.

- - and - , 1978: Structural studies of the development of infection structures of cowpea rust, Uromyces phaseoli var. vignae. I. Nucleoli and nuclei. Can. J. Bot. 56, 648-661.

- -, and M. A. STUMPF, 1986: Ultrastructural observations of penetration sites of the cowpea rust fungus in untreated and silicon-depleted French bean cells. Physiol. Mol. Plant Pathol. 29, $27-39$.

- -, 1987: Host or nonhost resistance. In: ARntZen, Ch. J., and C. Ryan (Eds), Molecular strategies for crop protection, pp. 25-34. Alan Liss, New York.

$\mathrm{HOCH}, \mathrm{H}$. C., and R. C. STAPLES, 1987: Structural and chemical changes among the rust fungi during appressorium development. Annu. Rev. Phytopathol. 25, 231-247.

- - , - - B. WHITEHEAD, J. COMEAU, and E. D. WOLF, 1987: Signaling for growth orientation and cell differentiation by surface topography in Uromyces. Science 235, 1659-1662.

Holden, D. W., and R. Rohringer, 1985: Proteins in intercellular washing fluid from noninoculated and rust-affected leaves of wheat and barley. Plant Physiol. 78, 715-723.

Hoppe, H. H., B. Humme, and R. Heiteruss, 1980: Elictor induced accumulation of phytoalexins in healthy and rust infected leaves of Phaseolus vulgaris. Phytopath. Z. 97, 85-88.

JoHnson, T., 1934: A tropic response in germ tubes of urediospores of Puccinia graminis tritici. Phytopathology 24, 80-82.

KAPOORIA, R. G., and K. MENDGEN, 1985: Infection structures and their surface changes during differentiation in Uromyces fabae. Phytopath. Z. 113, 317-323.

KeEN, N. T., 1982: Specific recognition in gene for gene host parasite system. Advances in Plant Pathology 1, 35-82.

KIM, W. K., and N. K. HOWES, 1987: Localization of glycopeptides and race-variable polypeptides in urediosporelings and urediosporelings walls of Puccinia graminis tritici; affinity to concanavalin A, soybean agglutinin, and Lotus lectin. Can. J. Bot. 65, 1785-1791.

KITANI, K., and Y. INOUE, 1961: "Studies on the soybean rust and its control measure." Part I. Shekoku Agric. Exp. Stan., Zentsuji, Japan.

KNAUF, G., and K. MENDGEN, 1988: Secretion-systems and membrane-associated structures in rust fungi after high pressure freezing and freeze-fracturing. (submitted.)

KOCH, E., 1984: Untersuchungen zur Biologie des Sojabohnenrostes (Phakopsora pachyrbizi Syd.) und zur Charakterisierung der Rostresistenz von Sojabohnenzuchtlinien. Dissertation Universität Göttingen.

KUNOH, H., 1987: Induced susceptibility and enhanced resistance at the cellular level in barley coleoptiles. In: Nishimura, S., C. P. VANCE, and N. DOKE (Eds), Molecular determinants of plant diseases, pp. 59-73. Springer Verlag, Berlin.

LEWIS, B. C., and J. R. DAY, 1972: Behaviour of urediospore germ-tubes of Puccinia graminis tritici in relation to the fine structure of wheat leaf surfaces. Trans. Br. mycol. Soc. 58, 139-145.

LitTLEFIELD, L. J., and C. E. BRACKER, 1972: Ultrastructural specialization of the host-pathogen interface in rust infected flax. Protoplasma 74, 271-305.

- - , and M. C. HeAth, 1979: "Ultrastructure of Rust Fungi." Academic Press, New York. 
Luke, H. H., R. D. BarnetT, and P. L. Pfahler, 1987: Xenoparasite - Nonhost Reactions in Puccinia-Gramineae Pathosystems. Phytopathology 77, 1488-1491.

MACKO, V., J. A. A. RENWICK, and J. F. RISSLER, 1978: Acrolein induces differentiation of infection structures in the wheat stem rust fungus. Science 199, 442-443.

Maheshwari, R., and A. C. HiLdebRANDT, 1967: Directional growth of the urediospore germ tubes and stomatal penetration. Nature (London) 214, 1145-1156.

MAYAMA, S., 1983: The role of avenalumin in the resistance of oats to crown rust. Memoirs of Faculty of Agriculture, Kagawa Universicy 42, 1-64.

Mendgen, K., 1973: Feinbau der Infektionsstrukturen von Uromyces phaseoli. Phytopath. Z. 78, 109-120.

— - 1981: Nutrient uptake in rust fungi. Phytopachology 71, 983-989.

- - 1982: Differential recognition of the outer and inner walls of epidermal cells by a rust fungus. Naturwissenschaften 69, 502-503.

- -, M. LANGE, and K. BRETSCHNEIDER, 1985: Quantitative estimation of the surface carbohydrates on the infection structures of rust fungi with enzymes and lectins. Arch. Microbiol. 140, $307-311$.

- - , and P. NASS, 1988: The activity of powdery mildew haustoria after feeding the host cells with different sugars, as measured with a potentiometric cyanine dye. Planta 174, 283-288.

Moerschbacher, B., K. H. Kogel, U. Noll, and H. J. Reisener, 1986: An elicitor of the hypersensitive lignification response in wheat leaves isolated from the rust fungus Puccinia graminis F. sp. tritici. I. Partial purification and characterisation. Z. Naturforsch. $41 \mathrm{c}$, $830-838$.

Müller, M., and H. MOOR, 1984: Cryofixation of thick specimens by high pressure freezing. In: Science of Biological Specimen Preparation, SEM Inc., AMF O'Hare (Chicago), U.S.A., $131-138$.

NiKs, R. E., 1983: Haustorium formation by Puccinia bordei in leaves of hypersensitive, partially resistant, and nonhost plant genotypes. Phytopathology 73, 64-66.

Onoe, T., T. TANi, S. Minagawa, and H. SAGAwa, 1987: Ultrastructural changes of stomata in relation to specificity of rust fungi. In: Nishimura, S., C. P. VANCE, and N. DOKe (Eds), Molecular determinants of plant diseases, pp. 29-45. Springer Verlag Berlin.

Paradies, J., B. Hümme, H. H. Hoppe, R. Heitefuss, and E. F. Elstiner, 1979: Induction of ethylene formation in bean (Phaseolus vulgaris) hypocotyl segments by preparations isolated from germ tube cell walls of Uromyces phaseoli. Planta 146, 193-197.

- - und E. F. ElstNer, 1980: Wirt-Parasit Bezichungen: Untersuchungen zur Induktion der Äthylenbildung in Höheren Pflanzen und zur Rolle des Äthylens bei der Ausprägung von Krankheitssymptomen und der Einleitung von Abwehrreaktionen. Ber. Dtsch. Bot. Ges. 93, 635-657.

PAvgi, M. S., and J. G. DiCKSON, 1961: Influence of environmental factors on development of infection structures of Puccinia sorghi. Phytopathology 51, 224-226.

ROHRINGER, R., and J. W. MARTENS, 1987: Infection-related proteins in intercellular washing fluids from stem rust-affected leaves: race-associated protein differences revealed by PAGE and Con A blotting. Physiol. Mol. Plant Pathol. 31, 375-386.

RWENDEIRE, ABEL J., and M. J. BARNES, 1988: The initial response of barley to challenge by leaf rust (Puccinia hordei Otth): some factors in RNA metabolism related to resistance. Physiol. Mol. Plant Pathol. 32, 115-126.

SPEnCER-Philips, P. T. N., and J. L. GAY, 1981: Domains of ATPase in plasma membranes and transport through infected plant cells. New Phytologist 89, 393-400.

StAPLes, R. C., and H. C. Hoch, 1982: A possible role for microtubules in the induction of nuclear division in bean rust uredospore germlings. Exp. Mycology 6, 293-302.

- - H. J. Grambow, and H. C. HoCh, 1983: Potassium ion induces rust fungi to develop infection structures. Exp. Mycology 7, 40-46.

- - , and V. MACKO, 1984: Germination of urediospores and differentiation of infection structures. In: Bushnell, W. R., and A. P. Roelfs (Eds), The Cereal Rusts, pp. 255-289. Academic Press, Orlando.

- - and H. C. Hoch, 1987: Infection structures - form and function. Exp. Mycology 11, $163-169$. 
StumpF, M. A., and M. C. Heath, 1985: Cytological studies of the interactions between the cowpea rust fungus and silicon-depleted French bean plants. Physiol. Plant Pathol. 27, 369-385.

TANI, T., and H. Yamamoto, 1978: Nuclei acid and protein synthesis in association with the resistance of oat leaves to crown rust. Physiol. Plant Pathol. 12, 113-121.

Vanderplank, J. E., 1984: Disease Resistance in Plants. Academic Press, Orlando.

WELTER, K., M. MÜLLER, and K. MENDGEN, 1988: The hyphae of Uromyces appendiculatus within the leaf tissue after high pressure freezing and freeze substitution. Protoplasma (in press).

WYNN, W. K., 1976: Appressorium formation over stomata by the bean rust fungus: Response to a surface contact stimulus. Phytopathology 66, 136-146.

Yamamoto, H., H. Hokin, T. TANi, and G. Kadota, 1977: Phenylalanine ammonia-lyase in relation to the crown rust resistance of oat leaves. Phytopath. Z. 90, 203-211.

- - and T. TANI, 1986: Possible involvement of lipoxygenase in the mechanism of resistance of oats to Puccinia coronata avenae. J. Phytopathology 116, 329-337.

YounG, D. H., H. KÖHLE, and H. KRAuss, 1982: Effect of chitosan on membrane permeability of suspension-cultured Glycine max and Phaseolus vulgaris cells. Plant Physiology 70, 1449-1454.

ZIEGLER, E., and R. PONTZEN, 1982: Specific inhibition of glucan-elicited glyceollin accumulation in soybeans by an extracellular mannan-glycoprotein of Phytophthora megasperma f. sp. glycinea. Physiol. Plant Pathol. 20, 321-331. 